\title{
LOCALIZING BYZANTIUM: GROUP II ENAMELS ON THE RELIQUARY OF SAINT BLAISE IN DUBROVNIK
}

\author{
Ana Munk
}

\author{
A. Munk \\ University of Zagreb \\ Faculty of Humanities and Social Sciences \\ Department of History of Art \\ Ivana Lučića 3, HR-10000 Zagreb \\ amunk@ffzg.hr
}

\begin{abstract}
The article analyzes four enamel roundels on the reliquary of Saint Blaise in Dubrovnik Cathedral treasury. It has not been noticed previously that these enamels contain features which makes it unlikely that they were made in Constantinople. The lack of inscriptions which is more characteristic for Byzantinizing enamel work made in Italy, and the depiction of the two martyrs which does not reflect the codes set for Byzantine saints' attire indicate the artist's Italo-Byzantine training and, possibly, a local identity of the two martyrs. Stylistically, plain design of these enamels indicate a run of the mill manufacture that has not utilized all iconographical, coloristic and decorative options that an $11^{\text {th }}$ or $12^{\text {th }}$ century enamel workshop in Constantinople may have had at its disposal.
\end{abstract}

Key words: Saint Blaise reliquary, cloisonné enamel, Dubrovnik, Byzantine saints, Italo-Byzantine style, saints' attire

This contribution to studies in honor of professor Igor Fisković takes as its subject four enamel plaques on the reliquary of Saint Blaise, an artwork that testifies to Dubrovnik's earliest art and history, to which professor Fisković dedicated many years of his academic career (Fig. 1). The head relic of Saint Blaise was found in 1026, but the early history of the reliquary is unknown. The first mention dates to 1335 when the entry in the earliest inventory of Dubrovnik cathedral reads: "caput Beati Blasij epi. in bacino argenti." 1 Thus, some key issues concerning the history of this reliquary before its 1694 reconstruction by the Venetian goldsmith Francesco Ferro, ${ }^{2}$ as well as the date, style and the iconography of its enamel decoration have not been fully solved. In this study I intend to address four highly damaged enamel roundels that have been classified as group II enamels ${ }^{3}$ (Figs. 2a-2d). I will argue that these enamels do not show stylistic and iconographical conventions of Middle Byzantine enamel production in Constantinople, as assumed in previous, very brief studies. The depictions of two unnamed martyrs (Figs. 2c-2d) are especially problematic when compared with Byzantine, highly codified representation of male and female saints, indicating that the artist adjusted their appearance to localize them for native viewers. In its broadest, contemporary meaning, localization refers to a process of translating a product into different languages or adapting it for a specific country or region. ${ }^{4}$

\footnotetext{
${ }^{1}$ Ecclesiae et monasteria, Reliquie s.s. corporum repertae in Ecclesia Cathedrali S. Mariae Maioris d.d. 1335, Državni arhiv u Dubrovniku (State Archives in Dubrovnik).

${ }^{2}$ Ferro left his signature Fran.co Ferro Venet.o F. A. 1694 in golden wire just above the bottom rim. For archival records concerning Francesco Ferro (Ferri) see I. LENTIĆ, Dubrovački zlatari 1600-1900, Zagreb, 1984, 63-64.

${ }^{3}$ The enamel schedule is taken from L. MIRKOVIĆ, Relikvijar moštiju sv. Vlaha, in Spomenik, LXXXI, II.razred, br.63, Beograd, Srpska akademija nauka i umetnosti, 1934, p. 3-26.

${ }^{4}$ In technical fields, "localization" refers to an adaptation of a software product to local users and consumers.
} 


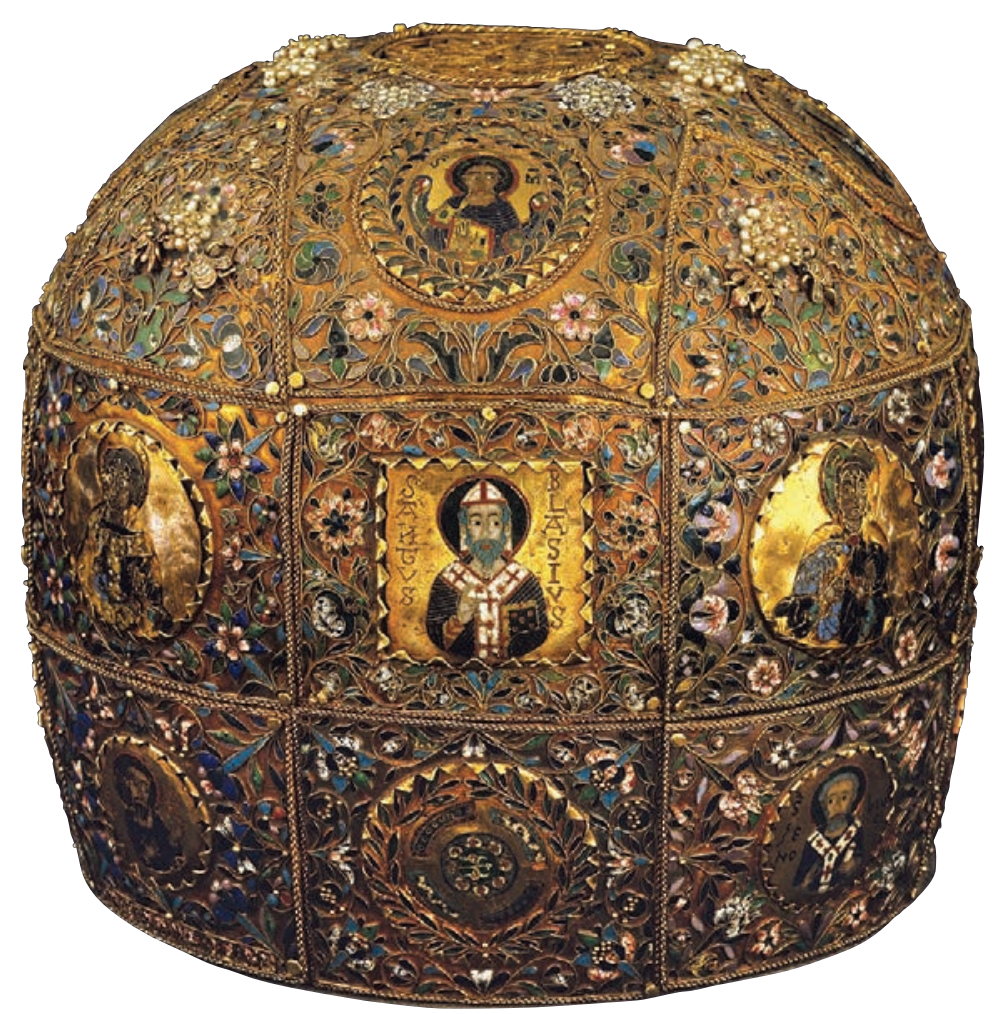

Fig. 1. Reliquary of Saint Blaise, Dubrovnik, Cathedral treasury

As we shall see, it was not only in Dubrovnik, but in other regions closely connected to Byzantine culture and aesthetics, that enamel works show iconographical adjustments in appearance of holy figures so to make them familiar to the viewing audience. This study can aim only to narrow the field of inquiry, as no iconographical study of group II enamels was done so far, and only a couple of brief notes on style and dating provided a starting point for this research.

\section{A NOTE ON REGIONAL ENAMEL WORKSHOPS}

The four enamels of group II were first discussed by Lazar Mirković, ${ }^{5}$ who dated them to the 10 th or $11^{\text {th }}$ century and considered them Byzantine because "there is nothing on them that would indicate that they were made in the West," a conclusion that we need to reconsider here. Vinicije Lupis accepted Mirković's dating, specified Constantinople provenance, and found some similarities with a Salonika enamel workshop, which also cannot be accepted. ${ }^{6}$ If these enamels were not made in Constantinople or Salonika, we need to search for another regional enamel workshop active in the Byzantine world in the period between the $11^{\text {th }}$ and $12^{\text {th }}$ century. The options are many and this task is aggravated by the fact that Byzantine enamel art is not a topic that has been studied comparati-

\footnotetext{
${ }^{5}$ No comparative material was provided. L. MIRKOVIĆ, Relikvijar moštiju, p. 17.

${ }^{6}$ V. LUPIS, B. GJUKIĆ, Emajlni reljefi na moćnicima sv. Vlaha, Dubrovnik, 2001, p. 16-17. It has been accepted in the literature that enamels from Salonika workshop date to ca. 1200, which is incompatible with the $10^{\text {th }}$ or the $11^{\text {th }}$ century date that Lupis proposes. For Salonika enamels, see: K. WESSEL, Byzantine Enamels: from the $5^{\text {th }}$ to the $13^{\text {th }}$ Century, Greenwich, Connecticut, New York Graphic Society Ltd, p. 185-191; The Glory of Byzantium: Art and Culture of the Middle Byzantine Era: A.D. 843-1261, H. C. EVANS and W. D. WIXOM (eds.), The Metropolitan Museum of Art, New York, 2006, p. 498; M. C. ROSS, S. R. ZWIRN, Catalogue of the Byzantine and Early Mediaeval Antiquities in the Dumbarton Oaks, Vol. 2, Jewelry, Enamels, and Art of the Migration Period, 1965, 2005, Dumbarton Oaks, Washington, D. C., p. 109-110.
} 

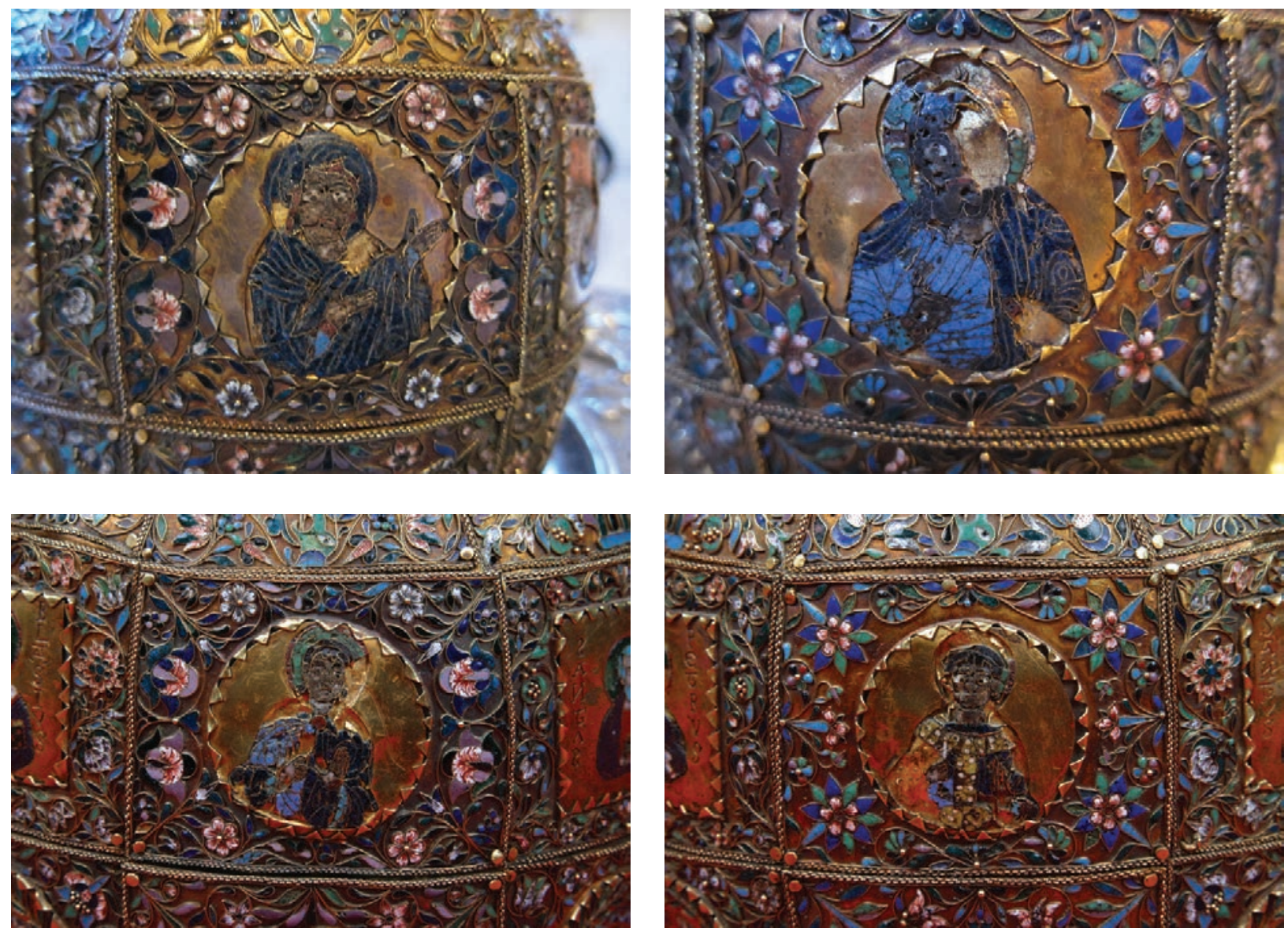

Fig. 2a) Reliquary of Saint Blaise, detail, diameter $4 \mathrm{~cm}$, The Virgin; 2b) Reliquary of Saint Blaise, detail, diameter $4 \mathrm{~cm}$, Christ ; 2c) Reliquary of Saint Blaise, detail, diameter $4 \mathrm{~cm}$, Male martyr; 2d) Reliquary of Saint Blaise, detail, diameter $4 \mathrm{~cm}$, Female martyr

vely and with the intent to establish common principles of regional adoption of Byzantine aesthetic and iconography outside Constantinople, and thus only a couple of observations can be offered here.

Regional workshops producing enamels with strong connections to Byzantium proper either through adoption of Byzantine aesthetics and techniques or through the presence of Greek artists have been identified in Salonika, Kiev, Georgia, Milano (possibly Pavia and Vercelli), ${ }^{7}$ Venice, Sicily and the Campagna region, all active through the $12^{\text {th }}$ century. The number of provincial workshops working in Byzantinizing idiom must have been, however, greater than assumed. ${ }^{8}$ Given the extensive artistic connections that Dubrovnik had with southern Italy, regional workshops in southern Italy are of particular interest to us in this context. ${ }^{9}$

The training that Montecassino goldsmiths received in Constantinople at the instigation of abbot Desiderius (1058-1087) is a crucial point in the history of enamel production in southern Italy. Desiderius, abbot of Montecassino, commissioned a paliotto in gold and enamels for the high altar of his celebrated church and has thus instigated a development of local goldsmith workshop in the Campagna region. Despite the Constantinople training and direct transmission of knowledge, the difference between Constantinople and Campagna enamel works is obvious, judging by the only work that is considered to have been a product of the "scuola desideriana," the Pantocrator crucifix in the Museo

\footnotetext{
${ }^{7}$ A. LIPINSKY, Oro, Argento, Gemme e Smalti dal $3^{00}$ A.C. al 1500, Firenze, 1975, p. 417.

${ }^{8} \mathrm{~K}$. WESSEL, op.cit., p. 17.

${ }^{9}$ E. ELBA, Miniatura in Dalmazia: I codici in beneventana (XI-XIII secolo), Taranto, 2011, p. 54-64.
} 


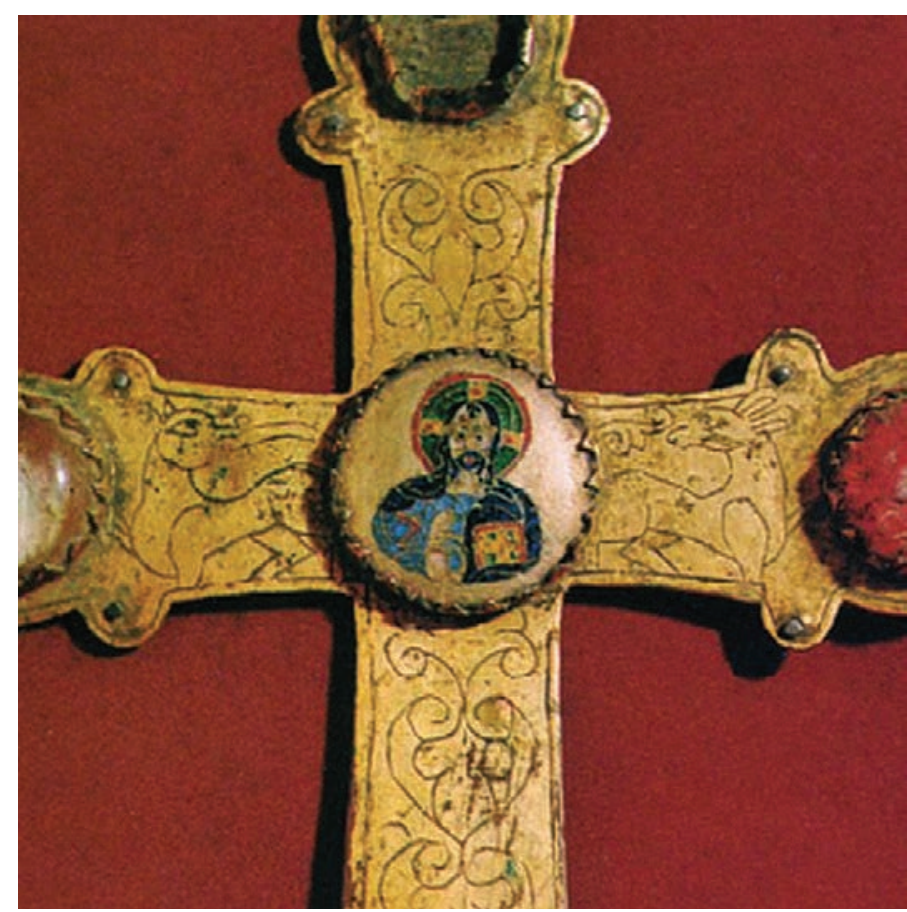

Fig. 3. Pantocrator Crucifix, Museo del Duomo di Gaeta, 11 th century

del Duomo di Gaeta (11 ${ }^{\text {th }}$ century, Fig. 3). It shows un-Byzantine characteristics that asserted themselves as soon as local artists were left to their own devices. ${ }^{10}$ Eventually local goldsmiths replaced the Greek ones introducing naturalistic elements in their base designs that, however, remained deeply rooted in Byzantine aesthetic. ${ }^{11}$

The interest in enamels as a quintessentially Byzantine luxury product was widespread in southern Italy. The most active, most highly-patronized, and stylistically most identifiable works came from a court workshop in Palermo, which is also the only southern Italian enamel workshop that is documented. Other workshops cannot be located more precisely even though they were engaged on ambitious projects. For instance, a $12^{\text {th }}$ to $13^{\text {th }}$ century enamel fragment showing a standing Christ (in Museo di Palazzo Venezia, Rome) testifies to the quality and longevity of regional enamel workshops in Southern Italy. This fragment is a sole survivor of a much more elaborate work, judging by its considerable size for an enamel piece (it is $67 \mathrm{~cm}$ high) and the exquisitely bejeweled Christ' halo. ${ }^{12}$ Scholars' uncertainties about the workshop that produced this piece (Byzantine or local?) and dating (12 ${ }^{\text {th }}$ or $13^{\text {th }}$ century?) strongly point to local provenance. Although I am not suggesting direct stylistic connection between Dubrovnik group II enamels and these southern Italian examples, deviations and involuntary slippages into Western mode is what connects them on a more general level as non-authentic Byzantine works.

\section{GROUP II ENAMELS: STYLE}

Group II enamels consists of four medallions of the same size, measuring $4 \mathrm{~cm}$ in diameter depicting Christ with a cruciform halo, the Virgin, and two unidentified martyrs who hold crosses in their hands. The Virgin is shown in a three-quarter pose extending her hands in prayer and supplication toward Christ (Fig. 2a). This is a common pose for the Virgin in the Deesis, and the matching image of John the Baptist must have been originally included.

As a group, it is obvious that these enamels do not show simple, yet firm drawing that characterizes $10^{\text {th }}$ century Byzantine enamels as demonstrated by datable examples, the votive crown of Leo VI (886-912), the Romanus chalice (dated to the reign of Romanus I Lacapenus, 920-944), the Limburg reliquary of $964-65$, and $10^{\text {th }}$ century enamels on Pala d'Oro. ${ }^{13}$ In these examples, the cloison line in folds is used sparingly and pallia folds are predominantly set widely apart (relative to the size

\footnotetext{
${ }^{10}$ E. GALASSO, Oreficeria medievale in Campagna: storia dell'oreficeria campagna 1, Federazione Orafi Campani, 2005, p. 52. A. LIPINSKY, op.cit., p. 418.

${ }^{11}$ The author assumes the existence of an independent workshop that remained in Campagna between the end of the $11^{\text {th }}$ and beginning of the $12^{\text {th }}$ century. E. GALASSO, op.cit, p. 52-55, cross Fig. 13.

${ }^{12}$ http://museopalazzovenezia.beniculturali.it/index.php?it/154/cristo-pantocrator

${ }^{13}$ For $10^{\text {th }}$ century enamels on Pala d'Oro, see J. DE LUIGI-POMORIŠAC, Les émaux byzantines de la Pala d'Oro de l'église de Saint-Marc à Venise, Zürich, 1966.
} 
of the figure). Folds are rendered as stripes alternating between dark and light colors thus creating a sharp contrast between the folds. Group II does not show such treatment of folds and cloison lines are rather free-flowing within areas of uniform color.

All four figures are rather robust and full-figured unlike more slender and narrow busts of Byzantine enamels of the $11^{\text {th }}$ century. A more slopping shape of the shoulders should be expected, as opposed to rounded shoulders of the male saint. Their faces are full and round with large eyes. Both martyrs appearyoung. Figures are well proportioned with a natural curve of the arms and the elbow extending sideways in the depiction of the male saint, adding a touch of movement, which we rarely see in Byzantine, stiff, and centered poses of saints depicted in bust length format.

As a way of demonstrating the difference between the Constantinople production

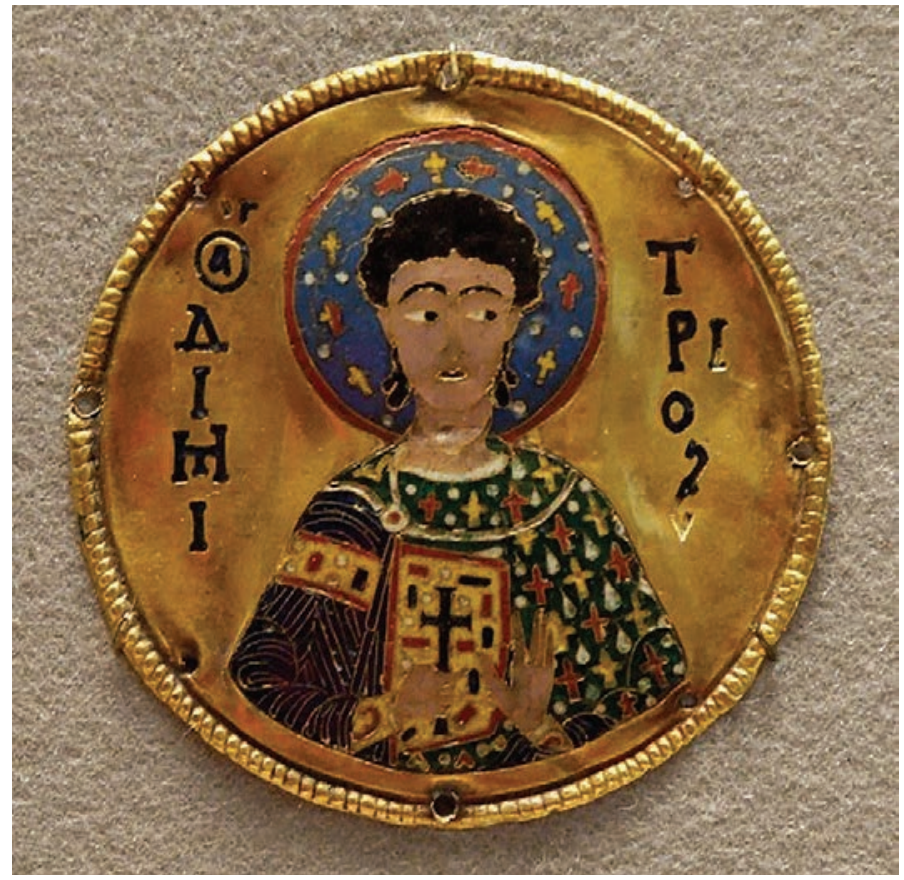

Fig. 4. St. Demetrios, Byzantine, enamel, diameter $8,25 \mathrm{~cm}$, (Diumati collection), Louvre, Paris, late $11^{\text {th }}$-early $12^{\text {th }}$ century and regional variations, I show here Saint Demetrios from the Djumati collection, ${ }^{14}$ an example of the Constantinople $11^{\text {th }}$ to $12^{\text {th }}$ century enamel production of the highest quality (Fig. 4). With his delicate facial features, firmly centered pose and opulent garment embellished with a variety of ornaments, the Demetrios enamel reflects the courtly taste of enamel work consumers. If we compare it with the Dubrovnik enamels, we can observe that the color palette in Dubrovnik enamels is reduced. Such restrain is uncharacteristic for Constantinople enamels where we find multicolored decorative touches even in standard production as in the case of 15 loose enamels of Byzantine provenance in the treasury of Saint Mark. ${ }^{15}$

The color scheme in the Dubrovnik enamels is rather simple on all figures, vested in dark blue for the pallium, lighter blue for the tunic, and turquoise for halos. There are very few traces of other colors and details other than (now darkened) red on the cuff on the Virgin's sleeve, her cap under the veil and the round clasp of the saint's tunic. Darkened yellow is used on the "pearl- studded" borders of one of the saint's garment, of which more will be said shortly (Fig. 2d). The color of the flesh endured the most damage, but some technical problems during firing should be assumed because the flesh pigment oxidized unevenly (note especially Christ's hands). Enamels are manufactured under extremely high temperatures $\left(700\right.$ to $800{ }^{\circ} \mathrm{C}$ ) through two or sometimes three firing, and thus uneven discoloration of flesh tones indicates that flesh pigment may have been affected in course of firing. ${ }^{16}$

\footnotetext{
${ }^{14}$ This and nine other exquisite enamels, dated to the late $11^{\text {th }}$ and early $12^{\text {th }}$ century, originally decorated the icon of Archangel Michael in Djumati monastery in Georgia. Their exceptional quality confirms their Constantinople provenance; Glory of Byzantium, p. 346-347, M. E. FRAZER, The Djumati Enamels: A Twelfth-Century Litany of Saints in: The Metropolitan Museum of Art Bulletin, 28, no. 6, 1970, p. 240-51.

${ }^{15}$ A. GRABAR, "Calicibizantini e patene bizantine medievali", in Il Tesoro di San Marco: Il Tesoro e il Museo, H. R. HAHNLOSER (ed.), Firenze, 1971, cat. 93-108, p. 82-86.

${ }^{16}$ The flesh color may have been affected by an inadequate amount of lead. "The lead was often added to lower the melting temperature of the glass and to act as a colorant...factors such as time of heating and whether there were oxidizing or reducing conditions in the furnace affected the final colors." C. STROMBERG, A Technical Study of Three Cloisonné Enamels from the Botkin Collection, in The Journal of the Walters Art Gallery, Vol. 46, 1988, p. 26. The earthquake in 1667 is likely to have caused the mechanical loss and the abrasion of the surface, but it was a less likely cause for the extreme discoloration of flesh tones.
} 
Decorative variety achieved with multitude of colors and details packed on a small surface is what gives a vibrant, luxurious quality to best enamels and what distinguishes enamels from other media. Even when figures' vestments are rendered in uniform color, one can still find a small area where the artist exhibits his skill in creating a multicolored variety. Another way to achieve variety was to segment the surface of uniform color into several sections, each showing a different geometric pattern of gold lines. This makes the large surface of the garment visually interesting (see, for instance, the variations in geometry of folds on the apostles' garments on the Pala d'Oro).

\section{PROBLEMATIC LACK OF INSCRIPTIONS}

Paul Hetherington questioned a common academic assumption that only the finest enamels were made in Constantinople, and those of lesser quality "somewhere else in the Mediterranean world." 17 However, the best indicator that these enamels were not made in the Greek-speaking world is the fact that these enamels do not have inscriptions, not even the most common abbreviations for Christ or Mary. Greek enamels without inscriptions practically do not exist and thus this issue deserves further discussion.

Inscriptions were paramount to Byzantine art in all media. An often-quoted story explains the importance of inscriptions in Byzantine art. The emperor's delegate, Gregory Melissenos, attending the Ferrara/Florence Council of 1483 refused to worship saints and Christ in a church he visited because he did not recognize them on account of the lack of inscriptions. He did not know "in what terms He (Christ) was inscribed." 18 In absence of textual clues, Gregory crossed himself and revered the sign he made on himself, and not "anything else that (he) saw (there)." While the number of Byzantine enamels without inscriptions is negligible, such enamels are frequent in enamel works produced in Italy. Note that the above-mentioned Pantocrator enamel in Gaeta cathedral collection does not have a sine qua non IC XC abbreviation for Christ (Fig. 3). A further example is Crux veliterna in Museo Diocesiano, Velletri (Fig. 5). ${ }^{19}$

Another possible reason for the absence of inscriptions in enamels may be that they were commissioned in Constantinople, but meant to be finished at home. There is a set of enamels on a book-cover of the Gospels of Mstislav in Moscow Historical Museum which explains the reason why enamel plaques made in Constantinople, but depicting local saints, were left unidentified. ${ }^{20}$ This was done so that local artists could finish them with inscriptions in local script as in other examples of Kievan enamel production. Two enamels from this set, the standing figures identified as local martyrs and princes, Boris and Gleb, provide a useful parallel with the Dubrovnik enamels insofar as they do not follow iconographically certain established codes in depicting male saints in Byzantium. They

\footnotetext{
${ }^{17}$ P. HETHERINGTON, Byzantine cloisonné enamel: Production, survival and loss, reprint in: P. HETHERINGTON, Enamels, Crowns, Relics and Icons: Studies on Luxury Arts in Byzantium, Burlington, 2008, p. 215.

${ }^{18} \mathrm{H}$. MAGUIRE, The Icons of their Bodies: Saints and their Image in Byzantium, Princeton, 1996, p. 46; P. L. GROTOWSKY, Defining the Byzantine Saint-Creating a Message in Byzantine Art, in: Towards Rewriting? New Approaches to Byzantine Archeology and Art, Proceedings of the Symposium on Byzantine Art and Archeology, Cracow, September 8-10, 2008, P. L. GROTOWSKY and S. SKRZYNIARZ (eds.), Warsaw, 2010, p. 134.

${ }^{19}$ This stauroteca was a gift to the cathedral of Velletri near Rome, possibly by the Pope Gregory IX (1227-1244). The cross features enamels from $9^{\text {th }}$ century (verso) of northern, Longobard provenance and $10^{\text {th }}$ century? enamels showing the Crucified with the Virgin, Saint John the Baptist and two unidentified saints, a male with a tonsure and a female (recto). The stauroteca was refashioned and enclosed in filigree work characteristic of the Palermo workshop of the first half of the $12^{\text {th }}$ century. I Papi della Memoria: La storia di alcuni grandi Pontefici che hanno segnato il cammino della Chiesa e dell'Umanità, Roma, p. 134. Hackenbroch considers the enamels on recto of this cross to be a work of a Byzantine artist in Italy, but notes unusual and uncharacteristically muddled colors for Byzantine work, Y. HACKENBROCH, Italienisches Email des frühen Mittelalters, Basel-Leipzig, 1938, p. 49-53, ill. p. 90.

${ }^{20} \mathrm{P}$. HETHERINGTON, Byzantine Enamels for a Russian Prince: The Book-Cover of the Gospels of Mstislav, in Zeitschrift für Kunstgeschichte 59, Munich 1996, reprint in: P. HETHERINGTON, Enamels, Crowns, Relics and Icons: Studies on Luxury Arts in Byzantium, Burlington, 2008, p. 310.
} 


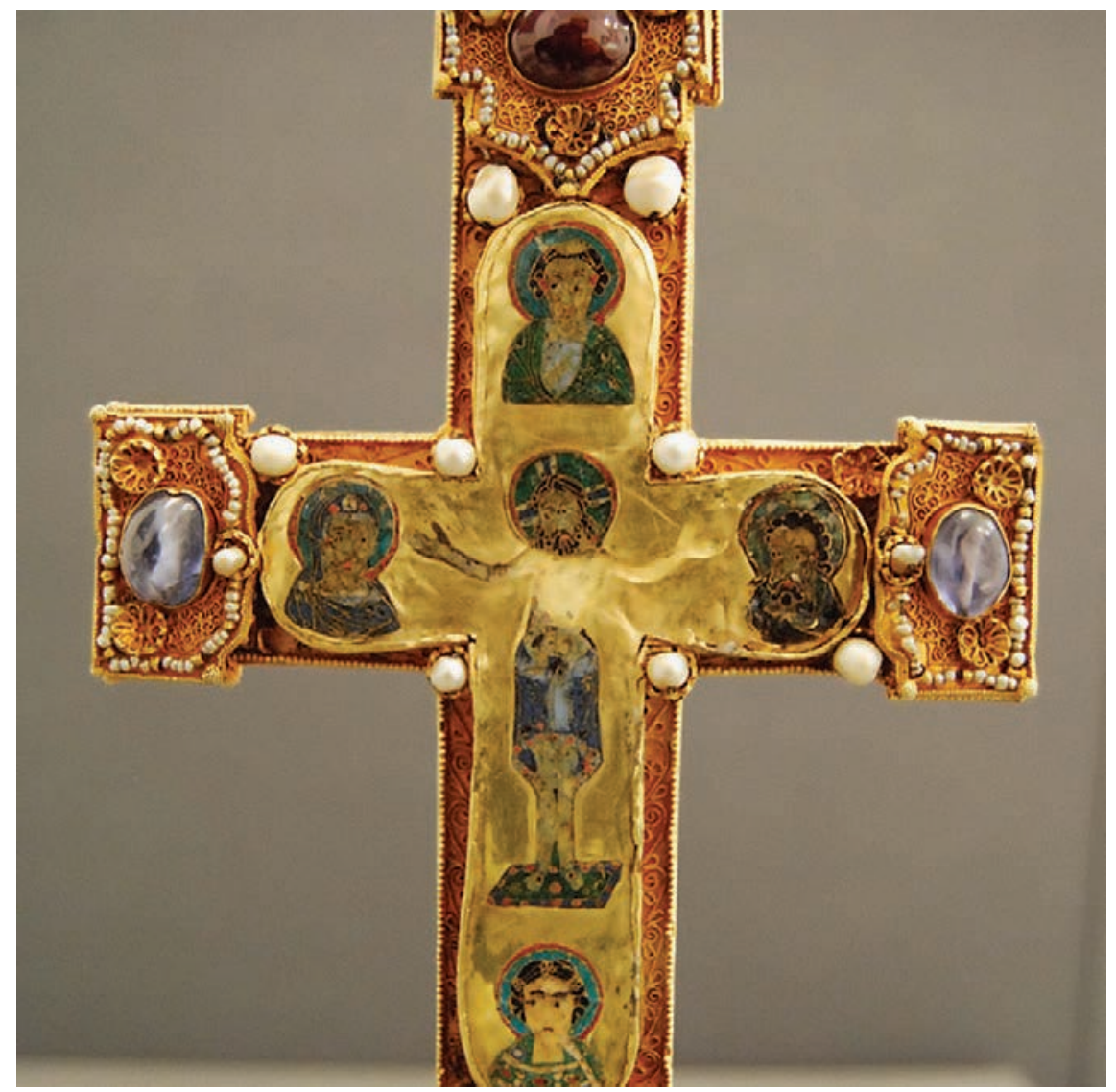

Fig. 5. Crux Velliterna, Museo Diocesiano, Velletri, enamels $10^{\text {th }}$ century?, filigree work $12^{\text {th }}$ century

wear diadems or high crowns that are distinctly not Byzantine (in addition to the fact that male martyrs in Byzantium do not wear crowns at all). Stylistically, however, they do not appear much different from what we would expect from Byzantine enamels and with the lack of identifying inscriptions their specific headgear is the only feature that distinguishes these figures from the rest of the set commissioned in Constantinople. This is not the case with Dubrovnik enamels, which do not appear custom-made by adding a few distinct attributes, but lack the style and iconography of Constantinople enamels entirely.

\section{TOWARDS THE CULTURAL IDENTITY OF SAINTS DEPICTED IN DUBROVNIK ENAMELS OF GROUP ॥}

The Western turn in local art can be pinpointed in the period after the Great schism and, specifically, after Dmitar Zvonimir was solemnly crowned by the Pope as the king of the Croats in 1076. As Emmanuela Elba argued, the Western turn had demonstrable effects on the choice of saints, their garment style, and overall, Italo-Byzantine, style of monumental and manuscript painting in Dubrovnik and the Elifite islands. ${ }^{21}$ When considering iconographical deviations from the Byzantine norms, we observe them in the vestments of the two saints. It needs to be emphasized that visual standards for depiction of saints in Byzantium were firmly set in the Middle Byzantine period. There was very little elbow room to play; bishops, monks, hermits, warriors and physician saints were base types while the individual saints within these categories were distinguished by facial physiognomy, attire, inscriptions and only occasionally by an attribute. The semantic field was restricted ${ }^{22}$ and specific combinations of dress and physiognomy that were once set were respected with amazing consistency.

\footnotetext{
${ }^{21}$ E. ELBA, op.cit, p. 62.

${ }^{22}$ GROTOWSKY, op.cit., p. 134.
} 
Our male martyr is young, dressed in a chlamys (cloak) that is held with a round red clasp centered in the middle of his chest and just below his neck (Fig. 2c). As insignificant as the position of the clasp may appear, it is a telling detail. They are three rather strict dress codes that Byzantium inherited from the Roman empire which are: imperial, clerical and a military dress. ${ }^{23}$ Our saint clearly does not wear either imperial or military garb. The clerical dress that Byzantine male martyrs mostly wear consists of a chlamys clasped on their right hand shoulder while they hold their crosses in front of the tablion (embroidered lozenge on the mantle). In enamels, this is done so to center the figure and emphasize the cross which is thus set apart from the ground, as seen in the example showing Saint Demetrios (Fig. 4) and in enamel roundels on Pala d'Oro. It is one of the Byzantine artists' habits of mind and hand to depict male martyrs in such a manner. We see in it countless line-ups of standing male martyrs in enamels and other painted or carved works. Regardless of the medium, the cross is placed in front of the mantle. ${ }^{24}$ Additionally, as in the Demetrios enamel, their tunics are adorned with an embroidered band encircling the upper sleeve of their right arm. In our case, however, the mantle lacks the tablion and the tunic shows no arm band or other sleeve adornments. The mantle does not fall over the middle of the chest and thus the cross is outlined against the tunic instead of the mantle. I examined the possibility that he could be one of Eastern martyrs dressed in short (or shorter) Persian cape (scaramangion) because such type of the cape is worn fastened in the middle of the chest, but a research in that direction has not brought convincing results. Particular combinations of garments in combination with specific facial features, hairstyle, head coverings and attributes are remarkably consistent in Byzantine art, but none of these combinations fit our martyr. The most likely explanation is that the artist did not have a strong contact with Byzantine culture and that his training was conducted within the Italo-Byzantine cultural sphere. In the Italo-Byzantine mural painting, Byzantine dress codes were more relaxed, and tablions and arm bands are not consistently depicted. ${ }^{25}$ The Dubrovnik martyr is not Byzantine through and through, and does not appear to have been celebrated by the Eastern Church. If we assume a Constantinople provenance for the Dubrovnik enamels, we would expect a much greater deal of adherence to known standards of dress code, regardless of the artist's aptitude.

The depiction of the female saint poses problems of a similar sort (Fig. $2 \mathrm{~d}$ ). To begin with, depictions of female figures, other than the Virgin Mary, and a few biblical figures such as Saint Anne and Saint Elizabeth, are very rare in Byzantine enamel production in general. Compared to a great number of male saints - there are 47 enamel plaques with half-length figures of male saints (not counting Apostles, prophets and Biblical figures) on the Pala d'Oro enamels--the absence of female saints is striking, but it is also expected given that women were not widely venerated in the Byzantine church. No strong iconographic tradition has been developed for holy women in Middle and Late Byzantine art, ${ }^{26}$ and the range of costumes, either imperial or monastic, is much more limited. This, however, makes the search for the cultural identity of the Dubrovnik female martyr somewhat easier.

\footnotetext{
${ }^{23}$ Ibidem, p. 142.

${ }^{24}$ Ivories such as the triptych icon with Deesis and Saints (Museo Sacro della Biblioteca Apostolica, Vatican, $10^{\text {th }}$ to $11^{\text {th }}$ century) and Harbaville Triptych (mid-11 $1^{\text {th }}$ century, Louvre) as well as the entire Romanos group of related ivories are particularly useful examples because of the number and variety of saints shown. They hold crosses against the tablion, and if tablion is not shown, an ornamented fibula with hanging adornments indicates the Roman origin of the garment. Monks do not show garment ornaments, but still wear their tunics clasped on the right hand shoulder. Only prophets and ascetics have their bodies completely concealed underneath the cloak gathered below the neck, but their age and worn out faces clearly denotes the category to which they belong.

${ }^{25}$ For instance in San Demetrio Corone (near Cosenza) in Sant'Adriano church, there are a several depictions of young martyrs that wear plain tunics. This is an extensive cycle of Italo-Byzantine frescoes dating to late $12^{\text {th }}$ or early $13^{\text {th }}$ century. They also show two female martyrs with vertically embroidered strap on tunics beneath their mantles, which also makes an interesting analogy with the dress of the female martyr in Dubrovnik enamels. For images consult: http://ica.princeton.edu/tomekovic/main.php? country $=$ Italy\&site $=\& v i e w=$ country\&page $={ }^{35}$

${ }^{26}$ For a summary and reasons for decline in women's participation in the Church after the $6^{\text {th }}$ century see introductory notes to A.-M. TALBOT, Holy Women of Byzantium: Ten Saints' Lives in English Translation, Washington, D.C., 1996, p. xi.
} 


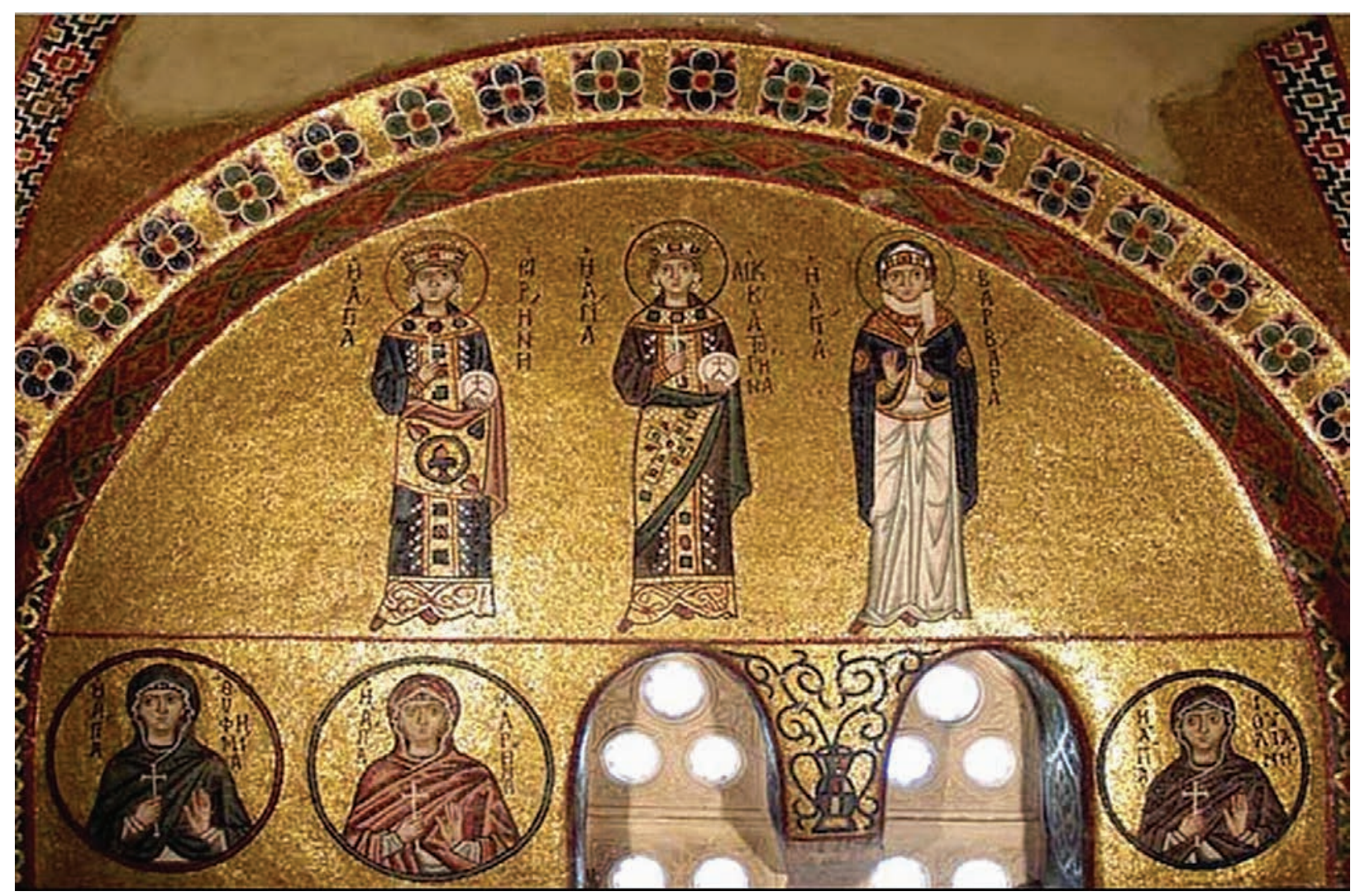

Fig. 6. Female saints, Hosios Loukas, mosaic, early $11^{\text {th }}$ century

She holds a small cross and wears a simplified, T-shaped loros consisting of a broad collar studded with "pearls." A stripe of the same width and fabric continues vertically down the middle of her bust and wraps around her waist. It is a garment laid above her tunic that derives from imperial costume, but she cannot be a Byzantine female saint of royal birth since her "loros" lacks a thorakion (a prominent shield-shaped part of the loros often adorned with a cross). It became part of the Byzantine saints' costume at the beginning of the $11^{\text {th }}$ century. ${ }^{27}$ Saints Catherine of Egypt, Catherine of Alexandria, Theodora, Irene, Pulcheria, Eudoxia, Cecilia, all wear it as a part of their imperial loroi. Disfigurations and misunderstandings in the depiction of the thorakion which "lost its principal characteristics... primarily in Italy" 28 started early in the Italo-Byzantine art leading to its disappearance and local varieties in holy female attire.

More importantly, she wears no crown as can be concluded from the outline of her head despite the considerable surface damage in this area. The crown is always worn in combination with the royal loros in Byzantine art. Moreover, her hair appears entirely uncovered. As no female of royal or purported aristocratic descent is depicted without a crown in Byzantium, no image of a nun exists with her head uncovered. ${ }^{29}$ Byzantine monastic female saints are depicted fully covered with the customary maphorion (obligatory head covering) and a body- concealing cloak. Byzantine female saints

\footnotetext{
${ }^{27}$ W. H. R. de COLLENBERG, Le 'thorakion': Recherches iconographiques, in Mélanges de l'Ecole française de Rome, MoyenAge, Temps modernes 83, 1971, p. 286-290. The first Byzantine empress to wear a thorakion is Zoe (1028-1050). This is also when it became part of royal and aristocratic female saints' costume. As empresses of the Comnenus dynasty started to wear the thorakion less often, it disappeared after 1204, but was retained as part of the costume of female saints in Byzantine art.

${ }^{28}$ Ibidem, p. 354-355.

29 "No image exist of a nun without a covered head," J. BALL, Decoding the Habit of the Byzantine Nun, in Journal of Modern Hellenism 27-28, 2009-2010, p. 32.
} 
shown in the mosaics in the katholikon of Hosios Loukas (early $11^{\text {th }}$ century) demonstrate two basic dress codes for females in post-iconoclastic Byzantium: royal and monastic (Fig. 6). Some significant details are used to differentiate them. For instance, a red maphorion and cloak denote Saint Marina, while the white under-tunic in the depiction of Saint Barbara makes her an abbess. ${ }^{30}$ In Italo-Byzantine art, however, female saints may appear with uncovered heads. The depiction of Saint Barbara in S. Maria della Croce, Casaranello (10 th century) shows her without a crown or veil, richly-dressed, but without a thorakion on her mantle as it would have been the case in contemporary Byzantine art. ${ }^{31}$ Saint Catherine depicted in the arcoslium of Santa Catarina church in Carpignano Salentino also appears with her hair uncovered. ${ }^{32}$

While there are no enamel depiction of female martyrs in existing Byzantine enamel works, not even one among many saints on Pala d'Oro, we find two luxury items in Italo-Byzantine enamel works that do. There is an unidentified female saint in the enamel roundel on crux Velliterna (Fig. 5). Her pretty young face with a stylish hairdo and uncovered head embellished with hair adornments in combination with the broad decorated collar places this work outside the Orthodox world. In this example, the artist respected local tradition in dress and hair ornament codes that were set much earlier, in Roman art. The book cover of Alfano (1173-1190, Capua, cathedral treasury) also shows three enamels that through the depiction of saints anchor the work in local culture. Here we find Saint Thomas Beckett, Saint Stephen and Saint Agatha, both patron saints of the cathedral of Capua. ${ }^{33}$ Agatha is depicted in the enamel roundel below the Crucifixion, identified by the inscription in Latin and a tiny cross in her hand. She is dressed in a light blue maphorion covering her head. A monastic cloak of the same color with a yellow border is clasped below her neck and covers her shoulders. Her cloak opens on her chest revealing a dark blue tunic embroidered vertically and around her waist with red and light blue ornaments. This particular detail sets her apart from the

\footnotetext{
${ }^{30}$ Over hundred male saints are depicted in these mosaics, but only a few females. The saints depicted are Irina, Catherine and Barbara (standing), Saint Euphemia, Marina and Juliana (in circles). Standing Saint Barbara is differentiated from the rest by wearing white under- tunic as a symbol of her higher ranking above nuns depicted in the medallions. Saint Marina's tunic and veil are red which points to her noble status, while generally, female veils and cloaks are dark as such dark garments were actually made of dark wool. On the opposite wall (to the right of the entrance to the church) is a lunette showing Constantine and Helena (standing) with bust length figures of Saint Agatha, Eugenia, Febronia, Anastasia and Thecla, all dressed in the same manner and with same facial features, except Saint Thecla who is additionally holding a book on account of her teaching.

${ }^{31}$ This image is usually dated to the $13^{\text {th }}$ century, but Linda Safran makes a strong case for the $10^{\text {th }}$ century dating when the first layer of frescoes were painted. L. SAFRAN, Reading Some South Italian Frescoes: The First Layer at S. Pietro, Otranto, and the Earliest Paintings at S. Maria della Croce, Casaranello, in Byzantion 60 (1990), p. 307-333.

${ }^{32}$ These frescoes are considered the oldest surviving Byzantine mural paintings in southern Italy and date from late $10^{\text {th }}$ to early $11^{\text {th }}$ century. Saint Cristina is depicted five times in the space of the church. See discussion in L. SAFRAN, Byzantine South Italy: New Light on the Oldest Wall Paintings, in Byzantinischen Malerei, Bildprogramme-Ikonographie-Stil, G. KOCH (ed.), Weisbaden, 2000, p. 257-74; L. SAFRAN, The Art of Veneration: Saints and Villages in the Salento and the Mani, in Les Villages dans l'empire byzantin ( $I V^{e}-X V^{e}$ siècle), J. LEFORT, C. MORRISSON and J.-P. SODINI (eds.), 179-92, Paris, 2005, p. 179-192.

${ }^{33}$ For the present discussion, I signal the use of saints to localize, and even personalize this work. Namely the choice of Saint Thomas Beckett, here depicted for the first time, is linked to the embassy of the archbishop Alfano de Camerota of Capua (1158-1180) to England and the work was probably a royal gift to Alfano commemorating this event. F. POMARICI, "L'Oreficeria", in I Normani: popolo d'Europa 1030-1200, M. D’ONOFRIO (ed.), Venezia, 1994, p. 276-277, cat. no. $3^{33}$ a-b; Splendori di Bisanzio, Testimonianze e Riflessi d'arte e Cultura Bizantina Nelle Chiese d'Italia, G. MORELLO (ed.), 1990, Milano, cat. no. 77, p. 194; Y. HACKENBROCH, op.cit., p. 58-61. Details: http://www. chiesacattolica.it/bewebxdbattisteri/heritage/work/4462791/Orefice+meridionale+sec. +XII\%2C+Lastrine+in + oro $+e+$ pietre+dure +34 . Saint Agatha was venerated in Sicily since $5^{\text {th }}-6^{\text {th }}$ century, E. FOLLIERI, Il culto dei santi nell'Italia Greca, in La chiesa Greca in Italia dall'VIII al XVI secolo: Atti del convegno storico interecclesiale, Italia Sacra: Studi e documenti di storia ecclesiastica, M. MACCARRONE, G.G. MEERSSEMAN, E. PASSERIN D'ENTRÊVES (ed.), Padova, 1972, p. 559.
} 
depictions of Byzantine nuns who are depicted completely covered with the mantle, and no embroidery or personal adornments can be seen, in compliance with the Byzantine taste for sobriety and modesty in the depiction of female monastic garments. The other specifically chosen figure on the Alfano book cover is Saint Thomas Beckett whose presence here is related to archbishop Alfano's embassy to England. Thus these two images of saints add a strong local, personal, and notably Latin flair to the object.

The garment of our saint is thus exceptional in Byzantine art of this period and may be pointing to a local choice of the saint and, I would suggest, to Roman origin of such iconography. She may be one of the Roman martyrs honored in Dubrovnik. ${ }^{34}$ The strongest contestants are Saints Domitilla and Patronilla whose relics were brought to Dubrovnik from Rome and had an important role in Pope Zacharias (741-752) attempts to extend his ecclesiastical influence of Rome in Ragusa. ${ }^{35}$

\section{CHRIST WITH A SCROLL}

A final note should be addressed to the image of Christ (Fig. 2b). Despite the considerable damage to the face, the figure of Christ is recognizable by His cruciform halo. His head slightly leans to the side, which gives Him a compassionate expression even though his facial features are unrecognizable. The cross is rendered in darkened red color outlined in white against the turquoise-colored halo. The outer rim of the halo is white. Miniscule circles are set within the turquoise halo, and can be seen at places where the color fell off revealing tiny gold circles still adhering to the ground. Such circles decorate the cuff of Christ's as well as the Virgin's sleeves and there are the only means the artist used to subdivide the surface and decorate the garments. A book in Christ's hand usually provides a suitable place to subdivide and adorn the surface, but here Christ holds a scroll. The clavus (often reduced to a vertical strap on His tunic) would also present an opportunity to add a decorative touch, but the artist restrained from it. The overall impression is one of simplicity of the overall design.

They are two iconographical features that appear unusual in the image of Christ. One is the lean of His head that breaks the hieratic formality of Christ's pose that is usually respected in Byzantine depictions of the Pantocrator or Christ in Deesis, of which this may be an abbreviated depiction. The second is the scroll in His left hand instead of the codex. Christ Child, Christ Emanuel, Christ in Ascension and in other scenes from His life, holds a scroll, but it is an exceptional attribute of Christ Pantocrator in Byzantine art. ${ }^{36}$ I am not aware of any example in enamel medium. Here again, we encounter a motif that lurks back to earlier Roman art rather than to Middle Byzantine artistic habits. Consider for instance, bust length depictions of Christ with a scroll in San Zeno mosaics or in mural painting in Santa Maria Foris Portas in Castelseprio which are clearly examples of $9^{\text {th }}$ century revivals of some paleo-Christian models. Even in provincial Italo-Byzantine mural paintings of southern Italy, Pantocrator holds a codex. ${ }^{37}$

\footnotetext{
${ }^{34}$ On the early, Roman, layer of Dubrovnik saints, see: T. ŽIVKOVIĆ, "The Earliest Cults of Saints in Ragusa", in T. ŽIVKOVIĆ, Forging Unity: South Slavs Between East and West: 550-1150, Institute of History, Belgrade, 2008, p. 147-156. ${ }^{35}$ In Živković's interpretation of Milletius' and Anonymous' chronicler accounts, the relics were brought by refugees who were iconophiles, which is another argument in favor that their iconography was formed in the West; Ibidem. ${ }^{36}$ The only Byzantine example of Pantocrator with a scroll that I am aware of is a bust length depiction of Christ with a scroll in the vault mosaic in the narthex of the church of the Dormition at Iznik (Nicea) (1065-1072), V. LAZAREV, Istorija vizantiskog slikarstva, Beograd, Fig. 267; C. MANGO, The date of the narthex mosaics of the Church of the Dormition at Nicaea, in Dumbarton Oaks Papers, Vol. 13, 1959, p. 245-252. The image of Pantocrator with the scroll has clearly survived from paleo Christian period in Carolingian art of the $9^{\text {th }}$ century. We find Him holding a scroll in Santa Maria Foris Portas in Castelseprio where he is depicted in half-length form within a circular frame.

${ }^{37}$ Guillou numbered 12 examples of the seated Christ, blessing and with the codex in Southern Italian painting from 959 until the $15^{\text {th }}$ century. A. GUILLOU, Art et religion dans l'Italie grecque medievale in: La chiesa Greca in Italia dall'VIII al XVI secolo: Atti del convegno storico interecclesiale, Italia Sacra: Studi e documenti di storia ecclesiastica, M. MACCARRONE, G.G. MEERSSEMAN, E. PASSERIN D’ENTRÊVES, Padova, 1972, p. 743.
} 
In conclusion, it has not been noticed previously that group II enamels on the reliquary of Saint Blaise contain un-Byzantine features that reflect the Italo-Byzantine sphere of enamel production. This could explain rather simple Latinized garments for saints, the lack of inscriptions, and the scroll in the Pantocrator's hand. Male and female martyrs do not adhere to codes set for Byzantine saints, which is to be expected for local saints whose iconography may have been already established in local art. That was also the case with two enamel works (crux Velliterna and Alfano book cover) where the depiction of female saints anchored the works in local ambiance. Stylistically, plain design of group II enamels indicate a run of the mill manufacture that has not utilized all iconographical, coloristic and decorative options that an $11^{\text {th }}$ or $12^{\text {th }}$ century enamel workshop in Constantinople may have had at its disposal. Regional enamel workshops in Southern Italy (and elsewhere) in this period were capable of emulating the Byzantine technique of enamel production often demonstrating a great skill in the use of cloison lines. Dubrovnik enamels are not without artistic merit, but, at the same time, they do not show the ease and flexibility in systematizing the cloison line as is the case in best examples of Constantinople provenance. I have already suggested that group I enamels on the reliquary of Saint Blaise were made in Dubrovnik, ${ }^{38}$ and believe that this may have been the case with the group II as well. The artist's Southern Italian training is very likely. Unfortunately, our perennial inability to identify more closely the origin of Byzantinizing works in Dalmatia within the vast and multi-layered landscape of Southern Italian art, presents itself again as a challenge which witch we are all too familiar.

\section{SMJEŠTANJE BIZANTA U LOKALNU SREDINU: EMAJLI GRUPE II NA RELIKVIJARU SV. VLAHA U DUBROVNIKU}

Tema rada su četiri kružne emajlne pločice na relikvijaru glave sv. Vlaha u riznici dubrovačke katedrale. Lazar Mirković je prvi uočio da emajli na relikvijaru ne pripadaju istom vremenu i radionici te ih je izdvojio kao zasebnu grupu (Grupa II), za razliku od dvanaest kružnih emajlnih pločica (Grupa I) i četiri emajlne pravokutne pločice koje čine grupu III. Ove emajlne pločice koje su izvorno ukrašavale tri razna predmeta, objedinio je 1694. venecijanski zlatar Francesco Ferro koji je izradio relikvijar te ga bogato ukrasio ovim emajlnim spolijama i višebojnim emajlom cvjetnog uzorka vlastite izrade. Lazar Mirković je smatrao da na emajlima druge grupe "nema ništa zapadnog" pa ih smatrao bizantskim radovima 10. ili 11. stoljeća, a tu tvrdnju je uz nekoliko pojašnjenja prihvatio i Vinicije Lupis, specificirajući Konstantinopol kao mjesto izrade ovih emajla. U ovom radu se te teze pobijaju. Iako su emajli vrlo oštećeni, primjećuje se da stilska, a ponajviše ikonografska rješenja u prikazu Krista i dvaju neimenovanih svetaca pokazuju značajke zapadne ikonografije te tako odstupaju od vrlo ustaljenih navika bizantskih emajlista. Usporedbom sa najznačajnijom kolekcijom bizantskih emajla srednje bizantskog razdoblja, venecijanskom Pala d'Oro, i drugim nesumnjivo bizantskim emajlnim radovima, zaključuje se da ovi radovi nisu nastali u Konstantinopolu već u južnoj Italiji, a moguće i u Dubrovniku, kao što sam već predložila i za emajle prve grupe. Za treću grupu emajla već je dokazano i u literaturi prihvaćeno da se radi o emajlnim pločicama koje je Francesco Ferro prenio sa relikvijara ruke sv. Vlaha, a koje pokazuju sve odlike carske zlatarske radionice u Palermu. Ostale dvije grupe nešto je složenije atribuirati jer nema jasnih stilskih paralela s radovima koji nesumnjivo nose lokalne stilske i ikonografske značajke, a koji su proizašli iz raznih neidentificiranih regionalnih radionica južne Italije. Ikonografska analiza se tako pokazuje kao mogući put utvrđivanja provenijencije.

Prva indikacija da se radi o lokanoj radionici je nedostatak natpisa. Gotovo je nemoguće naći bizantske emajle koji ne nose natpise u grčkom pismu, što je, međutim, dosta uobičajeno za emajle

\footnotetext{
${ }^{38}$ A. MUNK, Deconstructing the Myth of Byzantine Crown: The Head Reliquary of Saint Blaise in Dubrovnik, in Anali Zavoda za povijesne znanosti Hrvatske akademije znanosti i umjetnosti u Dubrovniku, (forthcoming, 2016).
} 
koji su nastali u južnoj Italiji. Nadalje, odjeća neimenovanih mučenika ne odgovara bizantskoj. U radu se naglašava da je odjeća pojedinih svetaca u bizantskoj umjetnosti srednje bizantskog razdoblja posve kodificirana, pa kombinacijom natpisa, odjeće, fizionomije i rjeđe atributa dolazimo do jasno prepoznatljivog identiteta pojedinog sveca. Dubrovački svetac nosi plašt prikopčan okruglom kopčom visoko smještenom povrh prsiju, za razliku od bizantskih mučenika koji se prikazuju odjeveni u antički chlamys prikopčan fibulom na desnom ramenu dok drže križ ispred ukrašenog tabliona. Odstupanja od bizantskih pravila naročito se primjećuju u prikazu ženske svetice koja je odjevena u pojednostavljeni loros, ali bez thorakiona (djela lorosa koji se prikazuje u obliku štita). Još važnije, svetica ne nosi krunu, a sine qua non atributa za bizantske svetice aristokratskog porijekla. Još je manja mogućnost da bi svetica mogla biti bizantska redovnica, isposnica, budući da se usprkos oštećenja čini da je prikazana nepokrivene glave tj. bez maphoriona što bi također bilo bez presedana za prikaze bizantskih svetica-redovnica, a za što, međutim, nalazimo primjere u italo bizantskim radovima u emajlu (Crux Velliterna, Museo Diocesiano, Velletri) i uopće u zapadnom srednjovjekovnom slikarstvu. Nadalje, u radu se napominje da nisu poznati bizantski prikazi Pantokratora sa svitkom u ruci u emajlu, a u slikarstvu ga nalazimo samo u jednom primjeru, u mozaiku iz 10. st. u Nicei.

Kao što je Paul Hetherington ustvrdio, malo je moguće da je bizantski zlatar specijaliziran za emajl radio u drugoj tehnici. Stilske i ikonografske usporedbe treba prvenstveno tražiti u istoj tehnici. Dubrovački emajli druge grupe pokazuju "skliznuća" u zapadni izraz koja bi se pojedinačno mogla pripisati nekoj regionalnoj radionici bližoj Konstantinopolu ili želji naručitelja, ali u konačnici, oni ipak, nisu bizantski. Predlaže se stoga, da je ikonografija dubrovačkih mučenika nastala na zapadu, vjerojatno u Rimu što bi bilo u skladu s rimskom tradicijom prikazivanja svetica u raznim varijantama bizantskog lorosa. Umjetnik je poštovao lokalnu tradiciju, pa je kao i u drugim južnotalijanskim radovima u emajlu (evanđelistar nadbiskupa Alfana s prikazom sv. Agate zaštitnice Capue i Thomasa Becketta) lokalizirao predmet uključujući dva prikaza lokalnih svetaca. Moguće je i da se radi o nekom o svetaca iz prvog hagiografskog sloja dubrovačkih zaštitnika.

Ključne riječi: Sv. Vlaho, relikvijar, čelijasti emajl, Dubrovnik, bizantski sveci, Italo-bizantski stil, svetačka odjeća 